\title{
What Does the Change in the FOMC's Statement of Objectives Mean?
}

\author{
Daniel L. Thornton, Vice President and Economic Adviser
}

I $\mathrm{t}$ is widely acknowledged that the Full Employment and Balanced Growth Act of 1978 (the HumphreyHawkins Full Employment Act) establishes price stability and full employment as national economic policy objectives. The Act requires the Federal Reserve to conduct monetary policy pursuant to achieving these two goals. Historically, the Federal Open Market Committee (FOMC) has been cautious not to state its policy objectives in terms of either full employment or the unemployment rate, preferring instead to state its objectives in terms of price stability and economic growth. This essay discusses the statement of the FOMC's objectives since the late 1970s and its recent emphasis on maximum sustainable employment and asks whether this change reflects a fundamental change in the FOMC approach to policy or is merely an attempt to explicitly acknowledge its mandate.

The Humphrey-Hawkins Full Employment Act was enacted on October 27, 1978, amid considerable debate among economists and policymakers about the extent to which the Fed (or any central bank) could control inflation. Some argued that the Fed had complete control in the long run, whereas others suggested that any central bank's ability to control inflation was limited. Paul Volcker became Chairman of the Federal Reserve in August 1979, and under his influence in October 1979 the FOMC changed policy dramatically with the stated goal of significantly reducing inflation. The success of this effort effectively ended the debate. Indeed, most central banks have adopted (either explicitly or implicitly) a numerical long-run inflation objective. ${ }^{1}$

In contrast, most economists believe that central banks have little or no ability to directly affect employment. The effect of monetary policy actions on employment is indirect and stems from central banks' ability to affect output growth in the short run and achieve price stability in the long run. In the short run, expansionary monetary policy causes interest rates to decline. All other things the same, lower interest rates increase consumption and investment spending (i.e., aggregate demand), which increases output and, consequently, employment. Most economists believe that the long-run levels of output and employment are determined by economic fundamentals (productivity, technology, the saving rate, and so on), which are unaffected by monetary policy. Hence, any effect of policy actions on output-and therefore, employment-is temporary. Thus, working to achieve price stability is all policymakers can do to promote the objective of full employment. Former Fed Chairman Alan Greenspan made this point in his Congressional testimony on February 16, 2005, when he said, "For our part, the Federal Reserve will pursue its statutory objectives of price stability and maximum sustainable employment - the latter of which we have learned can best be achieved in the long run by maintaining price stability." This means that in the long run, maximum sustainable employment and price stability are complements from a policy perspective: If policymakers achieve the latter, they have done the most they can to achieve the former. ${ }^{2}$

Until just recently, the FOMC has avoided references to full employment or the unemployment rate in stating its policy objectives. For example, at the conclusion of each FOMC meeting the Committee votes on a policy directive; this directive typically includes a statement of the Committee's policy objectives. The policy directive for Paul Volcker's first FOMC meeting (August 14, 1979) read, "The Federal Open Market Committee seeks to foster monetary and financial conditions that will resist inflationary pressures while encouraging moderate economic expansion and contributing to a sustainable pattern of international transactions." 3 Neither maximum sustainable employment nor the unemployment rate was mentioned. A similar statement appeared in every policy directive until the July 2-3, 1991, meeting. Then the directive was modified slightly to read, "The Federal Open Market Committee seeks monetary and financial conditions that will foster price stability and promote sustainable growth in output." 4 
In contrast, most economists believe that central banks have little or no ability to directly affect employment. The effect of monetary policy actions on employment is indirect and stems from central banks' ability to affect output growth in the short run and achieve price stability in the long run.

The exclusive focus on price stability and economic growth in the policy directive continued until December 2008. The October 28-29, 2008, policy directive began with the statement, "The Federal Open Market Committee seeks monetary and financial conditions that will foster price stability and promote sustainable growth in output," and ended with the statement, "The Committee will monitor economic and financial developments carefully and will act as needed to promote sustainable economic growth and price stability." ${ }^{5}$ By contrast, the December 15-16, 2008, directive began with the sentence used in the October directive but ended with "The System Open Market Account Manager and the Secretary will keep the Committee informed of ongoing developments regarding the System's balance sheet that could affect the attainment over time of the Committee's objectives of maximum employment and price stability" [italics added]. ${ }^{6}$ However, maximum employment was not mentioned in the FOMC's policy statement, ${ }^{7}$ which read, "The Federal Reserve will employ all available tools to promote the resumption of sustainable economic growth and to preserve price stability." 8

These last two quoted sentences have appeared at the beginning and end of each policy directive since December 2008; however, until the September 21, 2010, meeting, there was no reference to the objective of maximum employment elsewhere in the policy directive or in the FOMC's statement. The September statement read, "Measures of underlying inflation are currently at levels somewhat below those the Committee judges most consistent, over the longer run, with its mandate to promote maximum employment and price stability" [italics added]. ${ }^{9}$ Reference to the objective of maximum employment was more prominent in both the November 2-3, 2010, policy directive and the FOMC's policy statement. Both included the statement, "Consistent with its statutory mandate, the Committee seeks to foster maximum employment and price stability. Currently, the unemployment rate is elevated, and measures of underlying inflation are somewhat low, relative to levels that the Committee judges to be consistent, over the longer run, with its dual mandate." 10

It is not clear whether the direct reference to the objective of maximum sustainable employment reflects a change in the FOMC's belief regarding the extent to which its actions can affect employment or merely reflects a desire to explicitly recognize its mandate, perhaps motivated by the fact that the unemployment rate remains unacceptably high. In this regard, it is interesting to note that the unemployment rate was 8 percent or higher from November 1981 to January 1984 without a significant change in the wording of the FOMC's policy directive.

\footnotetext{
${ }^{1}$ Elsewhere I discuss reasons the profession might have reached this conclusion based on the actions of European central banks and conclude that "At a bare minimum, the U.S. experience accelerated the evolution to inflation targeting" (p. 97). See Thornton, Daniel L. "How Did We Get to Inflation Targeting and Where Do We Go Now? A Perspective from the U.S. Experience," in David Cobham, Øyvind Eitrheim, Stefan Gerlach, and Jan Qvigstad, eds., Twenty Years of Inflation Targeting: Lessons Learned and Future Prospects. Cambridge, UK: Cambridge University Press, 2010, pp. 90-110.

2 For other reasons to consider price stability and other policy objectives as complements from a policy perspective, see Thornton, Daniel L. "Monetary Policy Transparency: Transparent about What?" The Manchester School, September 2003, 71(5), pp. 478-97; and Thornton, Daniel L. "The Case for 'Inflation First' Monetary Policy," Federal Reserve Bank of St. Louis Economic Synopses, No. 47, December 12, 2009; http://research.stlouisfed.org/publications/es/09/ES0947.pdf.

${ }^{3}$ Federal Reserve Press Release, September 21, 1979, p. 10.

${ }^{4}$ Federal Reserve Press Release, August 23, 1991, p. 15.

${ }^{5}$ Minutes of the Federal Open Market Committee, October 28-29, 2008, p. 10.

${ }^{6}$ Federal Reserve Press Release, November 3, 2010.

7 The FOMC has released a statement at the conclusion of each meeting since May 1999.

${ }^{8}$ Federal Reserve Press Release, December 16, 2008.

${ }^{9}$ Federal Reserve Press Release, September 21, 2010.

10 Minutes of the Federal Open Market Committee, November 2-3, 2010, p. 9.
} 